\title{
Relationship among psychological well-being, resilience and coping with social and clinical features in Crohn's disease patients
}

\author{
Arlete Silva ACCIARI, Raquel Franco LEAL, Cláudio Saddy Rodrigues COY, \\ Cristiana Corrrêa DIAS and Maria de Lourdes Setsuko AYRIZONO
}

ABSTRACT - Background - Crohn's disease is chronic, requires prolonged treatment, affects the physical and psychosocial health of patients and may alter their routine, quality of life and well-being. Recent studies recommend monitoring the health of these patients considering physical, psychological and psychosocial aspects, because they are directly related to the disease activity. These studies highlight the relevance of patients' emotional and behavioral conditions and suggest that the identification of the factors that influence the psychological well-being, resilience and Coping in these patients can favor the proper treatment. Objective - To relate psychological well-being, resilience and Coping with social and clinical features of Crohn's disease patients. Methods - Prospective study including 104 patients with Crohn's disease, both genders and mean age of 39 years. Standardized scales were used to assess and to relate psychological well-being, resilience and Coping with social and clinical variables. A questionnaire to characterize the sample and standardized scales in data collection (psychological well-being, resilience pillars and Coping strategies inventory - Folkman \& Lazarus) were used. Descriptive analysis of data and statistics for comparison of results were performed. Results - There were significant differences $(P<0.05)$ showing better psychological well-being for male patients, those who without children, were not religious, were employed and were doing complementary activities in addition to clinical treatment. More resilience for the male gender, those who without children, were not religious, divorced, separated or widowed, that received some monthly income; who did not undergo surgery, had the first symptoms after 30 years old and who had complementary activity. There were also significant differences in the use of Coping: usually, women used more developed escape and avoidance strategies; single, married or in stable-union patients used more self-control; not religious used positive revaluation strategy; the ones who were employed showed more self-control and positive reassessment; the ones who had lower family income indicated that they used less the self-control; the ones who had higher family income used more positive re-evaluation; patients who were diagnosed with Crohn's disease between the second decade of life showed to use mores more the positive reassessment strategy than those who were 20 years old or younger. Conclusion - Social aspects influenced psychological well-being, resilience and Coping in patients with Crohn's disease more strongly than clinical aspects. It was possible to identify the profiles with better and worse psychological well-being, resilience and Coping of those who need more support, as well as to know the most used Coping strategies in the studied group.

HEADINGS - Crohn's disease. Inflammatory bowel diseases. Psychological adaptation. Psychological stress. Psychological resilience.

\section{INTRODUCTION}

The question of well-being and well-living has been the focus of Western civilization since the period of the Greek philosophers, and recently, it has shown to be a key concept in Health Psychology. However, studies concerning psychology have occurred only in the second half of the 20th century, when Carol Ryff introduced the term psychological well-being in the Mental Health in 1950s and 1960s, and it has prevailed until nowadays. It is a multidimensional model that defines and describes six components of psychological well-being it indicate mental health and maturity: positive relations with others, autonomy, domain of the environment, personal growth, purpose of life and self-acceptance ${ }^{(1-6)}$.

Chronic diseases, including inflammatory bowel diseases (IBD), alter the well-being and life quality of patients. Several authors have highlighted the impact of Crohn's disease (CD) on health, lifestyle and routine of these patients. They suggest that health professionals should monitor psychological well-being of these patients and focus on relevant aspects in promoting patients' physical and psychosocial health, provide skills and strategies to deal with stress, and develop Coping for better adaptability after diagnosis and living with $\mathrm{DC}^{(7-11)}$.

Although the role of stress remains controversial in the IBD etiology, psychological stress has been associated with the disease activity. Interrelationships between stress and CD activity have been identified. The severity of $\mathrm{CD}$ has a direct influence on the disease perception. These perceptions have a direct influence on stress, which has a direct relationship influence with inadequate Coping and poor quality of patients' life ${ }^{(12-17)}$.

The concept of Coping arises in association with stress. Coping is a set of strategies used by people to deal with internal and external demands in stressful situations to adapt to adverse or stressful, chronic or acute circumstances. These actions can be acquired or voluntary, focusing on the problem or on the emotion generated $^{(18-21)}$. 
Recent studies evaluating Coping in IBD patients indicate that these perceptions of the disease and Coping have a significant impact, and modifiable factors of the disease can provide targets for multidisciplinary interventions to improve their quality of life. They also suggest that the patient's point of view on their health and wellbeing can support health professionals to focus on relevant well-being aspect in clinical practice ${ }^{(10,16,22-23)}$. Quick et al. ${ }^{(11)}$ recommend that health professionals should monitor the psychological well-being of young adults with IBD and provide them with these skills and strategies to deal with stress by favoring adequate Coping.

Associated with stress and Coping we have the concept of resilience, which implies stress resistance modalities, the capacity of facing, continuing and promoting a positive adaptation despite the high stress index. It also strengthens the Self to adapt to their behavior, to renew their attitudes in the face of adverse situations and to promote learning from the experiences. It is a kind of protective resource of the human being to maintain and recover level of normal adequate adaptation ${ }^{(24-25)}$.

Stress, Coping and well-being in IBD patients are associated with the capacity of the individual's resilience to integrative care. Actions to promote resilience are a path of symptoms self-regulation and lifestyle change through self-knowledge ${ }^{(10,26-28)}$.

These studies are important because the incidence and prevalence of IBD has increased over the past 50 years and require lengthy follow-up. In this context, patients with CD have suffer from the physical and psychosocial repercussions for decades, imposing on them a long period of treatment and differentiated care with health, adaptation to a new routine, style and quality of life ${ }^{(3,4,11,29)}$. Besides, it is necessary to consider the individuality, the dynamic perspective of the human being and the specificities of the conditions of life of each person. In this sense, to know the possible relations between the clinical and social aspects of CD patients with their psychological well-being, resilience and Coping can generate knowledge to support the assertiveness of the health team to improve intervention strategies and favor effective actions in their care. However, there are few studies which address this issue. Therefore, the purpose of this study was to relate psychological well-being, resilience and Coping with social and clinical feature of CD patients.

\section{METHODS}

Prospective and quantitative study involving one hundred and four CD patients of both genders and age between 18 and 65 years was performed. Patients with an unconfirmed diagnosis of $\mathrm{CD}$, with intestinal stomas, previous or evident diagnosis of schizophrenia or psychosis, bedridden or hospitalized patients, loss of follow-up, and those who did not agree to participate in the study, were excluded.

Dependent variables were psychological well-being, Coping and resilience. Independent variables were social features (gender, age, marital status, having children or not, education, occupation, family income and practice of religion) and clinical features (time since diagnosis, time since onset symptoms, drug treatment, hospitalization, surgery and complementary activity).

Patients were recruited at the IBD Outpatient Clinic and the data were collected between February 2015 and March 2016. The patients completed all questionnaires themselves.

The project was approved by Research Ethics Committee and registered (CAAE number 34579714.4.0000.5404). All participants were informed about the objectives of the study and signed the Informed Consent Form.

The following evaluation instruments were used:

\section{a) Questionnaire for sample characterization}

It was prepared to obtain social information of participants (gender, age, marital status, having children or not, practice of religion, education, occupation and family income); and clinical dates of participants (time since diagnosis, time since onset symptoms, drug treatment, hospitalizations, surgeries performed and complementary activities).

\section{b) Psychological Well-Being Scale (PWBS)}

It consists of 84 items that evaluate psychological well-being, divided into six components with 14 items: F1. Positive relations with others, F2. Autonomy, F3. Domain of the environment, F4. Personal growth, F5. Purpose of life and F6. Self-acceptance. It was used the Portuguese version, adapted by Machado ${ }^{(30)}$ from the original version of Ryff( ${ }^{(1)}$ and tested by Ryff $\& \operatorname{Keyes}^{(31)}$. It is a multidimensional construct that reflects characteristics of positive psychological functioning through self-assessment.

\section{c) Resilience Pillars Scale (RPS)}

It is a scale with 90 items distributed randomly in 11 factors related to the pillars of resilience: F1. Positive acceptance of change, F2. Self-confidence, F3. Self-efficacy, F4. Good mood, F5. Emotional control, F6. Empathy, F7. Independence, F8. Professional guidance for the future, F9. Reflection, F10. Sociability and F11. Positive values. It was standardized by Cardoso \& Martins ${ }^{(32)}$ to aim to identify the characteristics that favor a resilient behavior in the face of adverse situations;

\section{d) Coping Strategies Inventory (Folkman \& Lazarus)}

It is an instrument of psychological evaluation that classifies Coping strategies used in stressful situations. It was translated and adapted into Portuguese by Savóia et al. ${ }^{(33)}$ based on Folkman \& Lazarus $^{(34)}$, being composed of 66 items distributed randomly in eight factors: F1. Comfort, F.2 Clearance, F3. Self-control, F4. Social support, F5. Acceptance of liability, F6. Escape-avoid, F7. Troubleshooting and F8. Positive evaluation.

\section{Data analysis}

Initially, descriptive study was used for the characterization of the sample, and then statistical analyze. The Student's t-test was performed for the paired variables and the analysis of variance ANOVA for unpaired variables. The Software XLSTAT 2016 was applied and the level of significance was set at $P<0.05$.

\section{RESULTS}

One hundred and four CD patients were analyzed. The mean age was 39 years (minimum 18 and maximum 60), the age for onset symptoms ranged from 15 to 30 years (mean 25) and the time of diagnosis ranged from 5 to 20 years (mean 11).

The majority were female $(66.3 \%)$, married or in a stable union $(57.7 \%)$, religious $(79.8 \%)$, employed $(47.2 \%)$, had children $(56.7 \%)$, complete or incomplete high school level $(46.1 \%)$, and had family income between two and three minimum wages $(51.0 \%)$ (TABLE 1$)$.

All participants were in outpatient follow-up, $85.6 \%$ were taking medication for $\mathrm{CD}, 74.0 \%$ had prior hospitalization, $59.6 \%$ underwent surgeries and $72.1 \%$ did some complementary activity (TABLE 1). 
TABLE 1. Sample characterization.

\begin{tabular}{|c|c|c|}
\hline Social and clinical features $(n=104)$ & $\mathrm{n}$ & $\%$ \\
\hline \multicolumn{3}{|l|}{ Gender } \\
\hline Female & 69 & 66.3 \\
\hline Male & 35 & 33.7 \\
\hline \multicolumn{3}{|l|}{ Marital status } \\
\hline Married/stable union & 60 & 57.7 \\
\hline Single & 35 & 33.7 \\
\hline Divorced/separated/widowed & 9 & 8.6 \\
\hline \multicolumn{3}{|l|}{ Children } \\
\hline Yes & 59 & 56.7 \\
\hline No & 45 & 43.3 \\
\hline \multicolumn{3}{|l|}{ Practice of religion } \\
\hline Yes & 83 & 79.8 \\
\hline No & 21 & 20.0 \\
\hline \multicolumn{3}{|l|}{ Ages (years) $($ middle ages $=39)$} \\
\hline $18-29$ & 27 & 26.0 \\
\hline $30-39$ & 30 & 28.8 \\
\hline $40-49$ & 19 & 18.3 \\
\hline $50-59$ & 20 & 19.2 \\
\hline$>60$ & 8 & 7.7 \\
\hline \multicolumn{3}{|l|}{ Education } \\
\hline Primary school complete or not & 19 & 28.3 \\
\hline Higgh school complete or not & 48 & 46.2 \\
\hline College complete or not & 37 & 35.5 \\
\hline \multicolumn{3}{|l|}{ Occupation } \\
\hline Employed & 49 & 47.2 \\
\hline Not employed & 25 & 24.0 \\
\hline \multicolumn{3}{|l|}{ Family Income (minimum wages) } \\
\hline$<1$ & 17 & 16.3 \\
\hline $1-3$ & 53 & 51.0 \\
\hline $3-5$ & 16 & 15.4 \\
\hline$>5$ & 18 & 17.3 \\
\hline \multicolumn{3}{|l|}{ Time since diagnosis (years) $($ middle $=10.9)$} \\
\hline$<5$ & 30 & 28.9 \\
\hline $5-10$ & 31 & 29.8 \\
\hline $11-20$ & 31 & 29.8 \\
\hline$>20$ & 12 & 11.5 \\
\hline \multicolumn{3}{|l|}{$\begin{array}{l}\text { Time since onset symptoms (years) } \\
\text { (middle }=24.9 \text { ) }\end{array}$} \\
\hline$<15$ & 16 & 15.4 \\
\hline $15-20$ & 33 & 31.7 \\
\hline $21-30$ & 24 & 23.1 \\
\hline$>30$ & 31 & 29.8 \\
\hline \multicolumn{3}{|l|}{ Previous hospitalization } \\
\hline Yes & 77 & 74.0 \\
\hline No & 27 & 26.0 \\
\hline \multicolumn{3}{|l|}{ Previous surgery } \\
\hline Yes & 62 & 59.6 \\
\hline No & 42 & 40.4 \\
\hline \multicolumn{3}{|l|}{ Current drug treatment } \\
\hline Yes & 89 & 85.6 \\
\hline No & 15 & 14.4 \\
\hline \multicolumn{3}{|l|}{ Complementary activity } \\
\hline Yes & 75 & 72.1 \\
\hline No & 29 & 27.9 \\
\hline
\end{tabular}

\section{PWBS and social features}

The patients who had better psychological well-being were: male gender $(P \mathrm{~F} 1=0.040$ and $P \mathrm{~F} 4=0.046)$, patients without children $(P$ total $=0.040, P \mathrm{~F} 1=0.021, P \mathrm{~F} 4=0.001$ and $P \mathrm{~F} 5=$ $0.027)$, those who were not religious $(P \mathrm{~F} 1=0.033)$, and were employed in relation to the patients receiving benefit from National Social Service Institute (NSSI) $(P F 4=0.029)$. No significant differences were found among the different ages, marital status, education and family income levels in relation to PWBS (TABLE 2).

\section{PWBS and clinical features}

Patients who were doing complementary activity presented better psychological well-being $(P F 1=0.040$ and $P F 4=0.046)$. There were no significant differences in PWBS and time since diagnosis, time since onset symptoms, drug treatment, hospitalization or surgeries (TABLE 3 ).

\section{RPS and social features}

Men were more resilient $(P$ total $=0.002, P F 2=0.004, P F 3=$ $0.002, P \mathrm{~F} 4=0.003, P \mathrm{~F} 5=0.001$ and $P \mathrm{~F} 9=0.001$ ), as well as patients without children $(P \mathrm{~F} 4=0.025$ and $P \mathrm{~F} 9=0.002)$ and those who were not religious $(P F 11=0.017)$. Also the divorced, separated or widowed were more resilient than single patients $(P \mathrm{~F} 3=0.027)$; those who were employed than those who received benefit from NSSI (Ptotal $=0.014$ and $P$ F2 $=0.034$ ); those who were employed than unemployed ones $(P \mathrm{~F} 3=0.034)$; and those who were employed or not than those who were receiving benefit of NSSI $(P \mathrm{~F} 7=$ $0.007)$. The least resilient were the patients with family income of a minimum wage $(P \mathrm{~F} 9=0.006)$ and with elementary education $(P \mathrm{~F} 9=0.002)$. No significant differences were found between age ranges in relation to RPS (TABLE 4).

\section{RPS and clinical features}

Patients whose time since onset symptoms appeared after 30 years old $(\mathrm{pF} 1=0.34)$, who did not undergo surgery $(P F 1=$ $0.026)$ and those who had complementary activity $(P \mathrm{~F} 4=0.044)$ were more resilient. The least resilience was among the patients whose time since onset symptoms was under 15 years old $(P \mathrm{~F} 8=$ 0.033 ). No significant differences were found regarding the time since onset symptoms, drug treatment and hospitalization (TABLE 5).

\section{Coping and social features}

Women usually developed the escape and avoidance strategy $(P \mathrm{~F} 6=0.018)$. Single, married, or stable-union patients developed more self-control than those who were divorced, separated or widowed $(P \mathrm{~F} 3=0.024)$. Those who were divorced, separated or widowed and not religious developed more positive reassessment strategy $(P F 8=0.040)$. Employed or unemployed patients showed more self-control than those who received benefit from NSSI $(P \mathrm{~F} 3=$ 0.049 ). While, those who were employed showed more positive re-evaluation than those who received benefit from NSSI $(P F 8=$ $0.011)$. Those who had a family income lower than a minimum wage used less the self-control strategy than those who received between one and five minimum wages $(P F 3=0.048)$; and those who had family income up to three minimum wages used more positive reassessment than those with lower income to minimum wage $(P F 8=0.027)$. No significant differences were found regarding age, having or not children and school level (TABLE 6). 
TABLE 2. Result and comparison ( $P$-value) among social features for PWBS.

\begin{tabular}{|c|c|c|c|c|c|c|c|}
\hline Features & \multicolumn{7}{|c|}{$P$-value } \\
\hline Female & $\mathrm{B}$ & A & $\mathrm{b}$ & $\mathrm{B}$ & A & A & $\mathrm{b}$ \\
\hline Male & A & A & a & A & A & A & a \\
\hline $18-29$ & A & A & A & $\mathrm{a}$ & a & A & A \\
\hline $30-39$ & A & A & A & $\mathrm{ab}$ & $\mathrm{b}$ & A & A \\
\hline $40-49$ & A & A & A & $\mathrm{b}$ & $\mathrm{b}$ & A & A \\
\hline Marital status ${ }^{(2)}$ & 0.513 & 0.638 & 0.152 & 0.855 & 0.927 & 0.437 & 0.856 \\
\hline Married/stable union & A & A & A & A & A & A & A \\
\hline Single & A & A & A & A & A & A & A \\
\hline Divorced/separated/widowed & A & $\mathrm{A}$ & A & A & A & A & A \\
\hline Children $^{(1)}$ & $0.021 *$ & 0.798 & 0.472 & $0.001 *$ & $0.027^{*}$ & 0.278 & $0.040 *$ \\
\hline Yes & B & A & A & $\mathrm{B}$ & B & A & B \\
\hline Education $^{(2)}$ & 0.725 & 0.897 & 0.569 & 0.314 & 0.175 & 0.891 & 0.664 \\
\hline Primary school complete or not & A & A & A & A & A & A & A \\
\hline High school complete or not & A & A & A & A & A & A & A \\
\hline College complete or not & A & A & A & A & A & A & A \\
\hline Occupation $^{(2)}$ & 0.982 & 0.325 & 0.183 & $0.029^{*}$ & 0.347 & 0.095 & 0.164 \\
\hline Employed & A & A & A & A & A & $\mathrm{a}$ & A \\
\hline Not employed & A & $\mathrm{A}$ & A & $A B$ & A & $\mathrm{ab}$ & A \\
\hline Benefit NSSI & A & $\mathrm{A}$ & A & $\mathrm{B}$ & $\mathrm{A}$ & $\mathrm{b}$ & A \\
\hline Family income (wages) ${ }^{(2)}$ & 0.230 & 0.949 & 0.959 & 0.080 & 0.293 & 0.806 & 0.597 \\
\hline$<1$ & A & A & A & $\mathrm{b}$ & A & A & A \\
\hline $1-3$ & A & A & A & $a b$ & A & A & A \\
\hline $3-5$ & A & $\mathrm{A}$ & A & $\mathrm{a}$ & A & A & A \\
\hline
\end{tabular}

${ }^{(1)}$ Student's t-test; ${ }^{(2)}$ ANOVA; *Significant at the level of $5 \%$ (A; B). Averages with common letters, for each variable, indicate that there is no significant difference among the categories.

TABLE 3. Result and comparison ( $P$-value) among clinics features for PWBS.

\begin{tabular}{|c|c|c|c|c|c|c|c|}
\hline \multirow{2}{*}{ Features } & \multicolumn{7}{|c|}{$P$-value } \\
\hline & F1 & F2 & F3 & F4 & F5 & F6 & Total \\
\hline Time since diagnosis (years) ${ }^{(2)}$ & 0.374 & 0.177 & 0.405 & 0.537 & 0.462 & 0.263 & 0.346 \\
\hline$<5$ & A & A & A & A & A & A & A \\
\hline $11-20$ & A & A & A & A & A & A & A \\
\hline$>20$ & A & A & A & A & A & A & A \\
\hline Time since onset symptoms (years) ${ }^{(2)}$ & 0.241 & 0.432 & 0.175 & 0.570 & 0.111 & 0.075 & 0.214 \\
\hline $21-30$ & A & A & A & A & A & $\mathrm{a}$ & A \\
\hline$>30$ & A & A & A & A & A & $\mathrm{a}$ & A \\
\hline Current drug treatment ${ }^{(1)}$ & 0.982 & 0.882 & 0.891 & 0.457 & 0.907 & 0.451 & 0.733 \\
\hline Yes & A & A & A & A & A & A & A \\
\hline Not & A & A & A & A & A & A & A \\
\hline Previous hospitalization $^{(1)}$ & 0.312 & 0.754 & 0.370 & 0.839 & 0.934 & 0.965 & 0.855 \\
\hline No & A & A & A & A & A & A & A \\
\hline Complementary activity $^{(1)}$ & $0.040 *$ & 0.404 & 0.093 & $0.046^{*}$ & 0.355 & 0.222 & 0.054 \\
\hline Yes & A & A & a & A & A & A & $\mathrm{a}$ \\
\hline No & B & A & $\mathrm{b}$ & B & A & A & $\mathrm{b}$ \\
\hline
\end{tabular}

${ }^{(1)}$ Student's t-test; ${ }^{(2)}$ ANOVA; *Significant at the level of $5 \%(\mathrm{~A} ; \mathrm{B})$. Averages with common letters, for each variable, indicate that there is no significant difference among the categories. 
TABLE 4. Result and comparison ( $P$-value) among social features for RPS.

\begin{tabular}{|c|c|c|c|c|c|c|c|c|c|c|c|c|}
\hline Features & \multicolumn{12}{|c|}{$P$-value } \\
\hline Female & A & $\mathrm{B}$ & $\mathrm{B}$ & $\mathrm{B}$ & $\mathrm{B}$ & A & A & A & $\mathrm{B}$ & A & A & $\mathrm{B}$ \\
\hline Male & A & A & A & A & A & A & A & A & A & A & A & A \\
\hline $18-29$ & A & A & A & A & A & A & A & A & A & A & A & A \\
\hline $30-39$ & A & A & A & A & A & A & A & A & A & A & A & A \\
\hline $40-49$ & A & A & A & A & A & A & A & A & A & A & A & A \\
\hline Marital status $^{(2)}$ & 0.677 & 0.351 & $0.027^{*}$ & 0.123 & 0.286 & 0.725 & 0.367 & 0.447 & 0.894 & 0.100 & 0.568 & 0.232 \\
\hline Married/stable union & A & A & $\mathrm{AB}$ & A & A & A & A & A & A & A & A & A \\
\hline Single & A & A & $\mathrm{B}$ & A & A & A & A & A & A & A & A & A \\
\hline Divorced/separated/widowed & A & A & A & A & A & A & A & A & A & A & A & A \\
\hline Children $^{(1)}$ & 0.463 & 0.949 & 0.968 & $0.025 *$ & 0.228 & 0.710 & 0.760 & 0.750 & $0.002 *$ & 0.682 & 0.258 & 0.441 \\
\hline Yes & A & A & A & $\mathrm{B}$ & A & A & A & A & $\mathrm{B}$ & A & A & A \\
\hline Education $^{(2)}$ & 0.093 & 0.947 & 0.400 & 0.110 & 0.983 & 0.464 & 0.949 & 0.334 & $0.002 *$ & 0.342 & 0.763 & 0.604 \\
\hline Primary school complete or not & $\mathrm{b}$ & A & A & A & A & A & A & A & B & A & A & A \\
\hline High school complete or not & $a b$ & A & A & A & A & A & A & A & A & A & A & A \\
\hline College complete or not & $\mathrm{a}$ & A & A & A & A & A & A & A & A & A & A & A \\
\hline Occupation $^{(2)}$ & 0.073 & $0.034^{*}$ & $0.034 *$ & 0.188 & 0.163 & 0.392 & $0.007^{*}$ & 0.055 & 0.138 & 0.113 & 0.709 & $0.014 *$ \\
\hline Employed & a & A & A & A & A & A & A & $\mathrm{ab}$ & A & A & $\mathrm{A}$ & A \\
\hline Not employed & $\mathrm{b}$ & $\mathrm{AB}$ & B & A & A & A & A & $\mathrm{a}$ & A & A & A & $\mathrm{AB}$ \\
\hline Benefit NSSI & $a b$ & $\mathrm{~B}$ & $\mathrm{AB}$ & A & A & A & B & $\mathrm{b}$ & A & A & A & $\mathrm{B}$ \\
\hline Family income (wages) ${ }^{(2)}$ & 0.849 & 0.735 & 0.485 & 0.872 & 0.958 & 0.876 & 0.787 & 0.839 & $0.006^{*}$ & 0.787 & 0.299 & 0.883 \\
\hline$<1$ & A & A & A & A & A & A & A & A & $\mathrm{B}$ & A & A & A \\
\hline $1-3$ & A & A & A & A & A & A & A & A & A & A & A & A \\
\hline $3-5$ & A & A & A & A & A & A & A & A & A & A & A & A \\
\hline
\end{tabular}

${ }^{(1)}$ Student's t-test; ${ }^{(2)}$ ANOVA. *Significant at the level of $5 \%$ (A; B). Averages with common letters, for each variable, indicate that there is no significant difference among the categories.

TABLE 5. Result and comparison ( $P$-value) among clinics features for RPS.

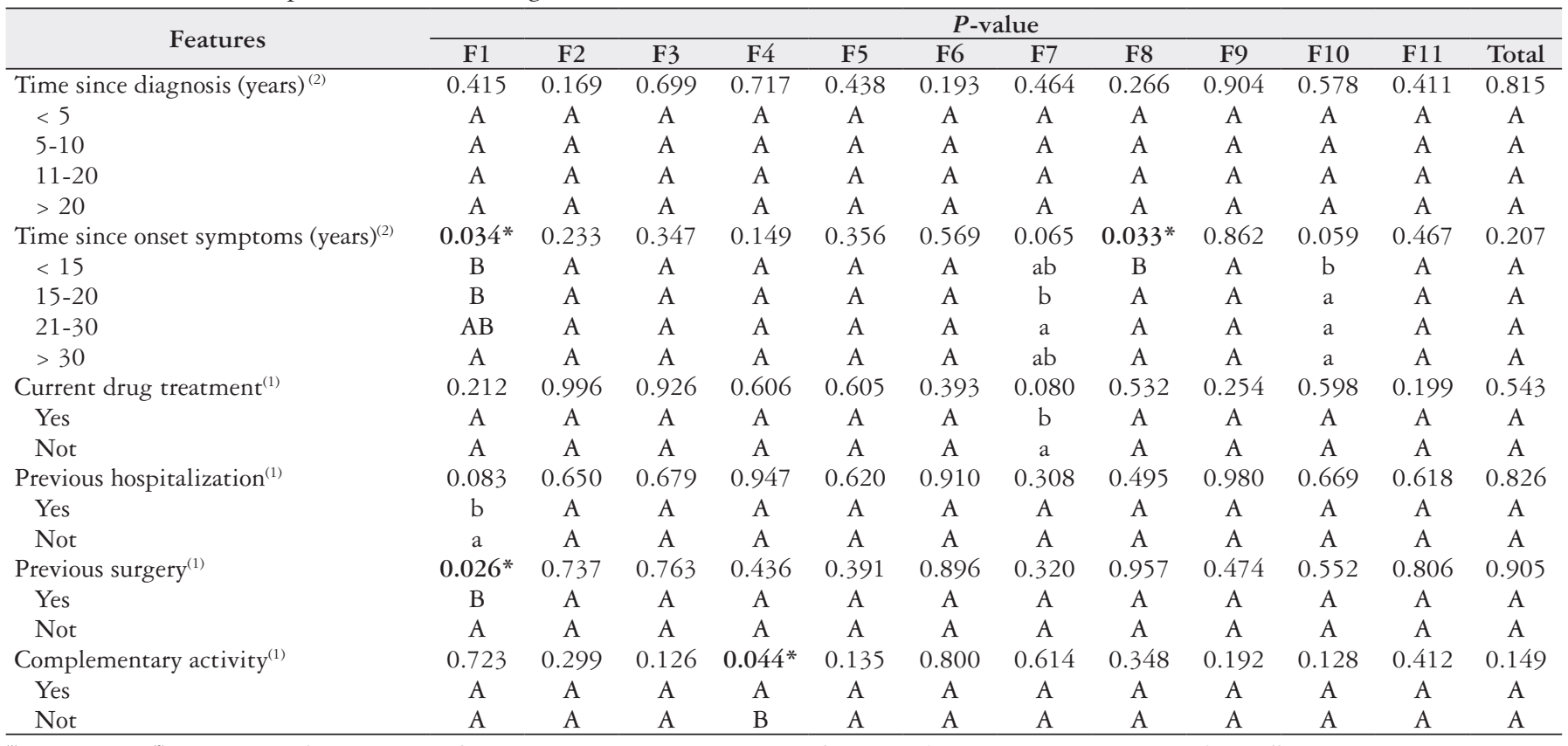

${ }^{(1)}$ Student's t-test; ${ }^{(2)}$ ANOVA. *Significant at the level of $5 \%(\mathrm{~A} ; \mathrm{B})$. Averages with common letters, for each variable, indicate that there is no significant difference among the categories. 
TABLE 6. Result and comparison ( $P$-value) among social features for Coping.

\begin{tabular}{|c|c|c|c|c|c|c|c|c|c|}
\hline \multirow{2}{*}{ Features } & \multicolumn{9}{|c|}{$P$-value } \\
\hline & F1 & F2 & F3 & F4 & F5 & F6 & F7 & F8 & Total \\
\hline Gender $^{(1)}$ & 0.763 & 0.121 & 0.343 & 0.492 & 0.520 & $0.018^{*}$ & 0.065 & 0.150 & 0.678 \\
\hline Female & A & A & A & A & A & A & $\mathrm{b}$ & A & A \\
\hline Male & A & A & A & A & A & B & a & A & A \\
\hline Ages (years) ${ }^{(2)}$ & 0.091 & 0.775 & 0.341 & 0.509 & 0.087 & 0.096 & 0.626 & 0.103 & 0.109 \\
\hline $18-29$ & $\mathrm{ab}$ & A & A & A & $a b$ & $\mathrm{ab}$ & A & A & A \\
\hline $40-49$ & $\mathrm{~b}$ & A & A & A & $\mathrm{b}$ & $\mathrm{ab}$ & A & A & A \\
\hline $50-59$ & $\mathrm{a}$ & A & A & A & $a b$ & $\mathrm{ab}$ & A & A & A \\
\hline$>60$ & $\mathrm{ab}$ & A & A & A & $a b$ & $\mathrm{~b}$ & A & A & A \\
\hline Marital status ${ }^{(2)}$ & 0.383 & 0.837 & $0.024 *$ & 0.627 & 0.065 & 0.656 & 0.966 & 0.698 & 0.949 \\
\hline Married/stable union & A & A & A & A & a & A & A & A & A \\
\hline Yes & A & $\mathrm{b}$ & $\mathrm{b}$ & A & A & A & A & $\mathrm{b}$ & $\mathrm{b}$ \\
\hline No & A & $\mathrm{a}$ & $\mathrm{a}$ & A & A & A & A & $\mathrm{a}$ & $\mathrm{a}$ \\
\hline Practice of religion $^{(1)}$ & 0529 & 0.623 & 0.285 & 0.136 & 0.245 & 0.838 & 0.635 & $0.040^{*}$ & 0.153 \\
\hline Yes & A & A & A & A & A & A & A & B & A \\
\hline No & A & A & A & A & A & A & A & A & A \\
\hline Education $^{(2)}$ & 0.977 & 0.936 & 0.820 & 0.423 & 0.093 & 0.532 & 0.130 & 0.444 & 0.429 \\
\hline Primary scholl complete or not & A & A & A & A & $\mathrm{a}$ & A & A & A & A \\
\hline High school complete or not & A & A & A & A & $\mathrm{b}$ & A & A & A & A \\
\hline College complete or not & A & A & A & A & $\mathrm{ab}$ & A & A & A & A \\
\hline Occupation $^{(2)}$ & 0.583 & 0.190 & $0.049 *$ & 0.644 & 0.648 & 0.965 & 0.069 & $0.011^{*}$ & 0.121 \\
\hline $3-5$ & A & A & A & A & A & A & A & A & A \\
\hline$>5$ & A & A & $\mathrm{AB}$ & A & A & A & A & A & A \\
\hline
\end{tabular}

${ }^{(1)}$ Student's t-test; ${ }^{(2)}$ ANOVA. *Significant at the level of $5 \%(\mathrm{~A} ; \mathrm{B})$. Averages with common letters, for each variable, indicate that there is no significant difference among the categories.

\section{Coping and clinical features}

Patients who were diagnosed between 21 and 30 years old developed more the positive reassessment strategy $(P F 8=0.031)$ than those younger than 20 years old. No significant differences were found for diagnostic time, drug treatment, hospitalization, surgery and complementary activity (TABLE 7).

\section{DISCUSSION}

$\mathrm{CD}$ is a chronic disease with physical and psychosocial repercussions that can affect them for several decades, a long period of treatment and requiring differentiated care. Recent studies highlight the relevance of patients' experiences in disease control and quality of life, focusing on psychological well-being, resilience and Coping ${ }^{(9-11,17,28)}$.
The present study, which relates psychological well-being, resilience and Coping with social and clinical aspects of $C D$ patients, evidenced that social features were more significant on Coping, psychological well-being and resilience than clinical one. This is probably because the social aspects are more dynamic, so they receive greater influence of the environment and have greater autonomy on the social features than the clinical aspects.

Dür et al. ${ }^{(10)}$ emphasize the importance of studies that seek to identify the patient's point of view on their health and well-being, since the data obtained can support the professionals to focus on the relevant points to better attend to them.

We observed in our study, better psychological well-being and positive relationships with others and personal growth in male gender. We also identified better resilience in the factors of self-confidence, self-efficacy, good humor, emotional control and 
TABLE 7. Result and comparison ( $P$-value) among clinics features for Coping.

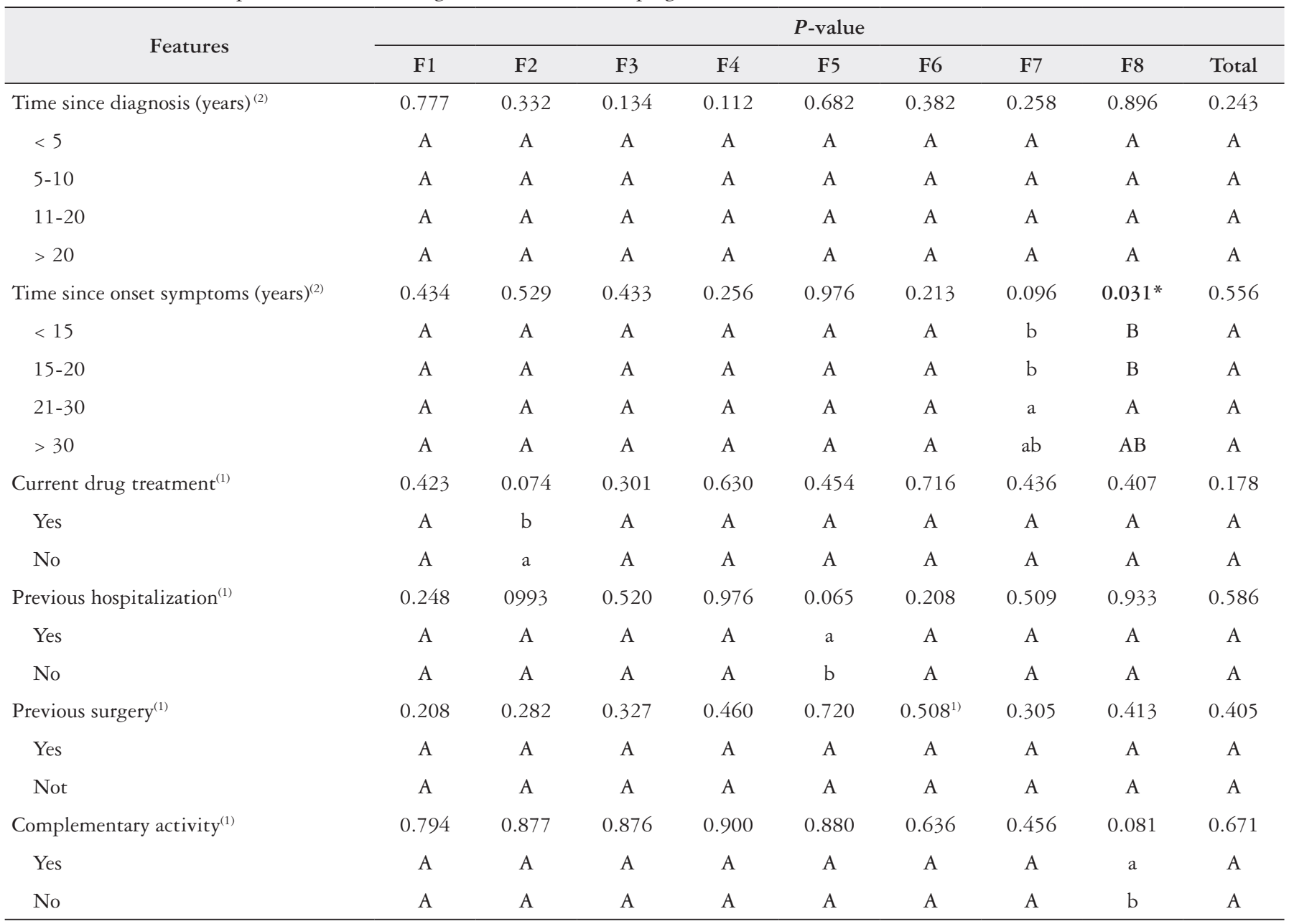

${ }^{(1)}$ Student's t-test; ${ }^{(2)}$ ANOVA; *Significant at the level of $5 \%(\mathrm{~A} ; \mathrm{B})$. Averages with common letters, for each variable, indicate that there is no significant difference among the categories.

reflection, as well as Bertuso-Pelá(26) and Carvalho et al. ${ }^{(35)}$. Most likely, women present these factors less developed, being more affected by emotions, which make them more fragile and insecure, consequently, needing more attention, external motivation and psychological support.

Carvalho et al. ${ }^{(35)}$ analyzed 120 patients with cardiovascular disease and observed that men have more resilience. They associated this feature with the fact that men use more problem solving strategies in Coping while women focus on emotional features.

Bertuso-Pelá( ${ }^{26)}$ observed that women face stress with a connotation of confrontation and emotional character, and use more escape and avoidance strategies, which may be associated with lower psychological well-being and resilience. They also demonstrate less self-confidence, self-efficacy, good humor, emotional control and reflection, and as a defense they resort to escape and avoidance.

Unlike Bertuso-Pelá's study ${ }^{(26)}$, the different age groups of our study did not influence the Coping, but marital status did. CD patients, who were single, married or in stable union, more commonly used self-control as a Coping strategy than those who were divorced, separated or widowed. However, the latter were more resilient than those who were single in the self-efficacy factor.
Possibly, conjugal life offers stimuli and challenges that favor the maturation and development of psychosocial skills, which improve readiness in problem solving and self-control.

In addition, psychological well-being and resilience were positively influenced in patients who had no children, in the positive relationships with others, personal growth, life purpose, good humor and reflection. This indicates that having children can bring challenges, require time investment and energy, cause mood changes, and stress and reduce possibilities of investment in personal growth. Therefore, having children is a variable that must be considered in the stress processes of CD patients, and this also must be monitored and treated for being associated with the disease activity as emphasized by Zhang et al. ${ }^{(17)}$.

Some studies have emphasized spirituality/religiosity as a protective factor of health with a tendency to favor better physical health, psychological well-being and quality of life ${ }^{(36,37)}$. However, in this study, CD patients who were not religious presented better psychological well-being in positive relationships with others. They were more resilient in positive values, and used the positive reassessment strategy in Coping with stress, showing optimism and personal empowerment in these factors. This data may suggest that these patients adopt a more rational posture and validate their 
own experience, whereas $\mathrm{CD}$ patients who were religious may be more dependent, pessimistic and fragile, requiring external and or superior support for personal resources.

Bertuso-Pelá's study ${ }^{(26)}$ showed that Coping among CD patients were affected by the educational variable, which we did not verified in our casuistic. On the other hand, the influence of education was evident on the reflection factor of the pillars of resilience in our patients. Patients with elementary education were less resilient than those with high school or college education. This probably indicates that the best intellectual condition favors resources for greater reflection, a positive factor in decision making and that may favor assertive choices in relation to one's own health. Therefore, it is recommended that the multiprofessional team consider that patients with lower educational level need more stimulation to reflect on aspects relevant to their well-being in the follow-up.

The variable occupation positively influenced the psychological well-being and resilience of $\mathrm{CD}$ patients, especially in personal growth, self-confidence, self-efficacy and independence. The employed patients demonstrated a significant development of the positive reassessment strategy in Coping, indicating that developing productive and remunerated activity reveals better health conditions, and also contributes to strengthen personal and psychosocial attributes. These aspects may generat favorable conditions for the development of the individual. Moreover, patients who do not work may require more attention and support, as they might have poor health and become more fragile, dependent and pessimistic in face of everyday events and well-being.

In the social feature, we observed an association between unemployed and lower monthly family income. Patients with household income of over one minimum wage were less resilient than those with higher income in the reflection factor. Moreover, they used less the strategy of self-control in Coping, while those who had a family income more than a minimum wage used more positive reevaluation. In this perspective, patients who had lower monthly family income showed less self-control, may be more impulsive and consequently may have reduced capacity to plan a positive change in their financial situation.

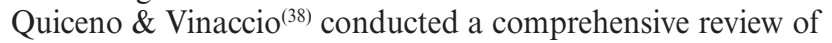
the literature on resilience in the perspective of chronic illness in the adult population and highlight resilience as an important construct, a protection factor for mental and physical health. They indicate that resilience can reduce pain, stress as well as increase quality of life and favor adaptation to disease.

In this sense, our results show that the age at onset symptoms and prior surgeries should be considered, since these aspects influenced the pillars of resilience. Patients who had the first symptoms under 15 years were less resilient in relation to the professional orientation for the future than those whose first symptoms appeared after 30 years old, who demonstrated better acceptance to change. Patients who did not undergo surgery had better resilience in the change acceptance factor. These data suggest that young patients require attention and guidance regarding future professional perspectives.

According to Riffi ${ }^{(39)}$, resilience is a recurrent and important theme for maintaining or regaining well-being in the face of adversity. Possibly, living with a long-term condition and undergoing several surgical procedures to control the disease recurrence requires adaptations that alter routine and lifestyle, trigger insecurities with persecutory thoughts. This may limit resilience and Coping because patients who had the first symptoms of $\mathrm{CD}$, between 21 to 30 years old developed more positive revaluation strategy than patients younger than 20 years old. For this reason, young patients must be treated not only during diagnosis and in the recurrence of the disease, but also monitored in all phases of the disease and offered psychological support for an assertive adaptation, helping in their self-knowledge, to deal with the disease and life challenges.

Skrautvol \& Náden ${ }^{(28)}$ emphasized the relevance of selfknowledge as the basis for the change in lifestyle as needed by IBD patients. Our study also showed that CD patients who were doing complementary activity presented better psychological well-being in positive relationships with others, in personal growth and were more resilient in the good mood factor. Supplementary activity may be a positive prophylactic factor for emotional state, social relationship and motivation for personal goals. These aspects may favor the control of the disease, since several authors establish straight relationships among emotional and psychosocial factors with greater CD activity and poorer quality of life $\mathrm{e}^{(7-10)}$.

No significant differences were found regarding the time since diagnosis of the disease, drug treatment and hospitalization, suggesting that these variables did not significantly influence psychological well-being, resilience or Coping in CD patients, the latter being also observed in Bertuso-Pelá's study ${ }^{(26)}$.

The limiting factors of the present study were relatively small sample size, short follow-up and subjectivity of the patient's selfevaluation. Besides, the patients were not evaluated at different stages of the disease. However, this study showed that social aspects had more influence on psychological well-being, resilience and Coping in patients with CD than clinical aspects. It allowed to recognize the profiles with better or worse psychological wellbeing, resilience and Coping, evidencing those who need more support. It also allowed to know the most used Coping strategies in the studied group. Moreover, these data can favor the actions of assertive care, helping them to deal better with the disease and stimulate actions that promote a more positive lifestyle. It also opens the way for future studies to test programs with the purpose of strengthening cognitive, emotional and social skills in $C D$ patients, producing new scientific evidence that could be implemented in clinical practice.

\section{ACKNOWLEDGEMENTS}

This study received collaboration from José Marcos M. Vendramini for statistical analysis and from Maria Lúcia Borelli Paradella for English edition.

\section{Authors' contribution}

Acciari AS: planning of the study, study design and organization, manuscript concept, literature research, patient recruitment, data collection, statistical analysis, data interpretation, writing and final revision of the manuscript. Leal RF: writing and final revision of manuscript. Coy CSR: patient recruitment and writing of manuscript. Dias CC: literature research and writing of manuscript. Ayrizono MLS: planning of the study, design study, manuscript concept, data interpretation, writing and final revision of manuscript.

\section{Orcid}

Arlete Silva Acciari. Orcid: 0000-0001-5272-0550.

Raquel Franco Leal. Orcid: 0000-0003-4285-4402.

Cláudio Saddy Rodrigues Coy. Orcid: 0000-0002-0916-4138.

Cristiana Corrrêa Dias. Orcid: 0000-0002-1354-394X.

Maria de Lourdes Setsuko Ayrizono. Orcid: 0000-0002-7035-2568. 
Acciari AS, Leal RF, Coy CSR, Dias CC, Ayrizono MLS. Relação entre bem-estar psicológico, resiliência e coping com fatores sociais e clínicos em pacientes com doença de Crohn. Arq Gastroenterol. 2019;56(2):131-40.

RESUMO - Contexto - A doença de Crohn é crônica, exige tratamento prolongado e afeta a saúde física e psicossocial dos pacientes podendo alterar sua rotina, qualidade de vida e bem-estar. Estudo recentes recomendam a monitoração da saúde destes pacientes considerando aspectos físicos, psicológicos e psicossociais, por estarem diretamente relacionados com a atividade da doença. Destacam a relevância das condições emocionais e comportais dos pacientes e sugerem que a identificação dos fatores que influenciam o bem-estar psicológico, resiliência e Coping nestes pacientes pode favorecer as ações de cuidado/tratamento apropriado. Objetivo - Relacionar bem-estar psicológico, resiliência e Coping com aspectos sociais e clínicos de pacientes com doença de Crohn. Métodos - Estudo prospectivo incluindo 104 pacientes portadores de doença de Crohn, ambos os sexos e idade média de 39 anos. Foi utilizado um questionário para caracterização da amostra e escalas padronizadas na coleta de dados (bem-estar psicológico, pilares de resiliência e inventário de estratégias de Coping de Folkman \& Lazrus). Realizada análise descritiva dos dados e estatística para comparação de resultados ( $P$-valor). Resultados - Foram identificadas diferenças significativas $(P<0,05)$ evidenciando melhor bem estar-psicológico para os pacientes do gênero masculino, aqueles que não possuíam filhos, não religiosos, com atividade profissional remunerada e que realizavam alguma atividade complementar ao tratamento clínico. Maior resiliência para o gênero masculino, aqueles que não possuíam filhos, não religiosos, divorciados, separados ou viúvos, que recebiam alguma renda mensal; que não passaram por cirurgia, tiveram os primeiros sintomas após 30 anos de idade e que faziam alguma atividade complementar ao tratamento clínico. Também foram observadas diferenças significativas no uso do Coping: as mulheres demonstraram usar mais a estratégia de fuga e esquiva; pacientes solteiros, casados ou em união estável utilizavam mais o autocontrole; não religiosos utilizavam mais a estratégia de reavaliação positiva; os que trabalhavam faziam mais uso do autocontrole e reavaliação positiva; os de menor renda familiar indicou usar menos o autocontrole e os de maior renda empregavam mais a reavaliação positiva; os que tiveram diagnóstico da doença de Crohn durante a segunda décadas de vida demonstraram utilizar mais a estratégia de reavaliação positiva que aqueles que tiveram diagnóstico em idade inferior a 20 anos. Conclusão - Aspectos sociais influenciaram mais fortemente o bem-estar psicológico, resiliência e Coping em pacientes com doença de Crohn que os aspectos clínicos. Possibilitou identificar os perfis com melhor e pior bem-estar psicológico, resiliência e Coping; aqueles que necessitam de maior apoio, bem como conhecer as estratégias de Coping mais utilizadas no grupo estudado.

DESCRITORES - Doença de Crohn. Doenças inflamatórias intestinais. Adaptação psicológica. Estresse psicológico. Resiliência psicológica.

\section{REFERENCES}

1. Ryff CD. Happiness is everything, or is it? Explorations on the meaning of psychological well-being. J Pers Soc Psychol. 1989;57:1069-81.

2. Veit CT, Ware JE. The structure of psychological distress and well-being in general populations. J Consult Clin Psychol. 1983;51:730-42.

3. Flambó PADG. Evaluation of psychological well-being in subjects with psoriasis. [Dissertation]. Lisboa (Portugal): Instituto Superior de Psicologia Aplicada; 2006. Available from: http://repositorio.ispa.pt/handle/10400.12/527

4. Jesus SN. Psychology of Health and well-being. Mudanças - Psicologia da Saúde. 2006;14:126-35.

5. Remédios CIFRN. Psychological well-being and personal and social skills in adolescence. [Dissertation]. Lisboa (Portugal): Universidade de Lisboa; 2010. Available from: http://repositorio.ul.pt/bitstream/10451/2792/1/ulfp037517_tm.pdf.

6. Machado ML, Bandeira DR. Psychological well-being: definition, evaluation and related principles. Est psicol. 2012;29:587-95.

7. Guthrie E, Jackson J, Shaffer J, MRCP, Thompson D, Tomenson B, Creed F. Psychological disorder and severity of inflammatory bowel disease predict helth-related quality of life in ulcerative colitis and Crohn's disease. Am J Gastroenterol. 2002;97:1994-99.

8. Caprilli R, Gassull MA, Escher JC, Moser C, Munkholm P, Forbes A, et al. European evidence based consensus on the diagnosis and management of Crohn's disease: special situations. Gut. 2006;55(Suppl I):36-58.

9. Souza MM, Barbosa DA, Espinosa MM, Belasco AGS. Quality of life of patients with inflammatory bowel disease. Acta Paul Enferm. 2011;24:479-84.

10. Dür M, Sadlonová M, Haider S, Binder A, Stoffer M, Coenen M, et al. Health determining concepts important to people with Crohn's disease and their coverage by patient-reported outcomes of health and wellbeing. J Crohns Colitis. 2014;8:45-55.

11. Quick V, McWlliams R, Byrd-Bredbenner C. A case-control study of current psychological well-being and weight-teasing history in young adults with and without bowel conditions. J Hum Nutr and Diet. 2015;28:28-36.

12. Duffy LC, Zielezny MA, Marshall JR. Relevance of major stress evented as an indicator of disease activity prevalence in inflammatory bowel disease. Behav Med. 1991;17:101-10.
13. Levenstein S. Stress and ulcerative colitis: convincing the doubting Thomases. Am J Gastroenterol. 2003;98:2112-15.

14. Sewitch MJ, Abrahamowicz M, Bitton A, Daly D Wild GE, Cohen A, et al. Psychological distress, social support, and disease activity in patients with inflammatory bowel disease. Am J Gastroenterol. 2001;96:1470-79.

15. Mawdsley JE, Rampton DS. Psychological stress in IBD: new insights into pathogenic and therapeutics implications. Gut. 2005;54:1481-91.

16. Danesh M, Gholamrazaei A, Torkzadeh F, Mirbagher L, Soluki R, Emami MH. Coping with stress in patients with inflammatory bowel disease and its relationship with disease activity, psychological disorders, and quality of life. Int J Body Mind Culture. 2015;2:95-104. Available from: http://ijbmc.org/index. php/ijbmc/article/view/29.

17. Zhang M, Hong L, Lin Y, Zheng S, Zhou X, Fan R, et al. Illness perceptions and stress: mediators between disease severity and psychological well-being and quality of life among patients with Crohn's disease. Patient Prefer and Adherence. 2016;10:2387-96.

18. Lazarus RS, Folkman S. Stress, appraisal and coping. New Work: Springer, 1984.

19. Antoniazzi AS, Dell'Aglio DD, Bandeira DR. The concept of coping: a theoretical view. Est Psicol. 1998;3:273-94.

20. Barnabé NC, Dell'Acqua MCQ. Coping strategies of ostomized individuals. Rev Latino-Am Enfermagem. 2008;16:712-19.

21. Leite-Junior JAP. Stress, coping strategy and quality of life in the work environment: a study at a research institute. [Dissertation]. Taubaté (SP): University of Taubaté; 2009. Available from: http://urlib.net/sid.inpe.br/ mtc-m18080/2009/05.27.19.53.

22. Iglesias-Rey, Barreiro-de MC, Caamaño-Isoma F, Rodriguez IV, VázquezGonzáles I, González AL, et al. How do psychological variables influence coping estrategies in inflammatory bowel disease. J Crohns Colitis. 2013;7:219-26.

23. van der Have M, Brakenhoff LKPM, Van Erp SJ, Kaptein AA, Leenders M, Scharloo M, et al. Back/joint pain, illness perceptions and coping are important predictors of quality of life and work productivity in patients with inflammatory bowel disease: a 12-month longitudinal study. J Crohns Colits. 2015;276-83.

24. Sinclair VG, Wallston LH. The development and psychometric evaluation of brief resilient coping scale. Assessment. 2004;11:94-101. 
25. Simão MJP, Saldanha V. Resilience and transpersonal psychology: strengthening values, actions and spirituality. Mundo Saúde. 2012;36:291-302.

26. Bertuso-Pelá EC. Stress and coping methods in patients with inflammatory bowel diseases. [Dissertation]. São Paulo (SP): University of São Paulo; 2007. Available from: www.teses.usp.br/teses/disponiveis/17/17138/tde-25082009.../mestrado usp.pdf.

27. Ribeiro P, Moraes R. Portuguese adaptation of the resilient coping brief scale Psic Saúde \& Doença. 2010;11:5-13. Available from: http://www.scielo.mec.pt/ scielo.php?script $=$ sci_abstract $\&$ pid $=$ S1645-00862010000100001\&lng $=$ pt\&n $\mathrm{rm}=\mathrm{iso} \& \operatorname{tlng}=\mathrm{en}$.

28. Skrautvol K, Náden D. Tolerance limits, sel-understanding, and stress resilience in integrative recovery of inflammatory bowel disease. Holisct Nurs Pract. 2017:31:30-41.

29. Kaplan GG. The global burden of IBD: from 2015 to 2025. Nat Rev Gastroenterol Hepatol. 2015;12:720-7.

30. Machado WL. Adapting the psychological well-being scale. [Dissertation]. Porto Alegre (RS): Federal University of Rio Grande do Sul; 2010. Available from: https:// www.lume.ufrgs.br/bitstream/handle/10183/98995/000869746.pdf?sequence=1

31. Ryff CD, Keyes CLM. The structure of Psychological well-being revisited. J Pers Soc Psychol. 1995;69:719-27.
32. Cardoso T, Matins MCF. Resilience pillar scale (RPS). São Paulo: Vetor, 2013.

33. Savóia MG, Santana PR, Mejias NP. Adapting the Folkman and Lazarus coping strategies inventory to Portuguese. Psicol USP. 1996;7:183-201. Available from: http://pepsic.bvsalud.org/scielo.php?pid=S1678-51771996000100009\&script=sci_abstract\&tlng=en.

34. Folkman S, Lazarus RS. If it changes it must be a process: study of emotion and coping during three stages of a college examination. J Pers Soc Psychol. 1985;48:50-70.

35. Carvalho IG, Bertolli ES, Paiva L, Rossi LA, Dantas RAS, Pompeu DA. Anxiety, depression, resilience and self-esteem in individuals with cardiovascular diseases. Rev Latino-Am Enfermagem. 2016;24;e2836.

36. Guimarães, HP, Avezum, A. The impact of spirituality on physical health. Rev Psiq Clín. 2007;34:88-94.

37. Panzini RG, Rocha NS, Ruschel D, Bandeira DR, Fleck MPA. Quality of life and spirituality. Rev Psiq Clín. 2007;34:105-15.

38. Quiceno JM, Venaccio S. Resilience: a perspective from the chronic disease in the adult population. Pensam Psicol. 2011;9:69-82. Available from: http://www. scielo.org.co/scielo.php?script=sci_abstract\&pid=S1657-89612011000200007.

39. Ryff CD. Psychological Well-Being Revisited Advances in Science and Practice. Psychother Psychosom. 2014;83:10-28. 